\title{
LESSONS LEARNED FROM THE ELECTORAL EXPERIENCE OF THE JUSTICE AND DEVELOPMENT PARTY (ADALET VE KALKINMA PARTI) 2002-2011
}

\author{
NADHERA MOHAMMAD QASSEM ${ }^{1}$, NOR HAFEZA MOHTAR ${ }^{2}$, AZHANA MOHAMAD $^{3}$
}

\begin{abstract}
This paper examines the electoral process in Turkey concerning the rise of the Justice Development Party (Adalet Ve Kalkinma Parti or AKP) and their experiences in the Turkish electoral process.. The evolution of AKP as a major opposition party until its electoral success is explored. The focal point of this paper is to examine the party's evolution, particularly in the area of changes in strategies, political agenda and responses to external and internal challenges. This study finds that AKP has managed to win consecutive Turkish elections and has maintained its support from the masses by means of moderate and modern approaches and reforms. This study is based on secondary sources. Books and scholarly articles concerning the issue were examined along with newspaper articles. Furthermore, this paper is purely a descriptive one and not based on any particular theory.
\end{abstract}

Keywords: Islamic party, secularism, Islamism, Kemalism, reforms

\section{ABSTRAK}

Makalah ini membahas tentang fenomena kebangkitan Partai Pembangunan Keadilan (Adalet Ve Kalkinma Parti atau AKP) dan pengalaman mereka dalam proses pemilihan umum di Turki. Evolusi AKP sejak menjadi partai oposisi hingga sukses memenangi pertarungan pemilu akan dieksplorasi. Titik fokus dari makalah ini adalah untuk menguji evolusi partai, khususnya di bidang perubahan strategi, agenda politik dan tanggapan terhadap tantangan eksternal dan internal. Studi ini menemukan bahwa AKP telah berhasil memenangkan pemilu Turki berturut-turut dan telah mempertahankan dukungan dari massa dengan menampilkan wajah yang moderat, modern dan reformatif. Penelitian ini didasarkan pada sumber-sumber sekunder. Buku dan artikel ilmiah mengenai masalah ini diperiksa bersama dengan artikel koran. Selanjutnya, makalah ini adalah murni deskriptif dan tidak didasarkan pada teori tertentu.

Kata kunci: partai Islam, sekularisme, Islamisme, Kemalisme, reformasi

\section{INTRODUCTION}

The history of Turkey is replete with a myriad of lessons concerning the political currents that continuously contest for power and sovereignty. The collapse of the Ottoman caliphate, the rise of Kemal Ataturk and the subsequent secularization of Turkey along with the rise of Islamism as a challenge to Kemalists, bear

historical significance to the fortunes of all political entities in which Islam is present. The rise of Islamism in Turkey heralds a threat to the secular establishment of the country. Being treated as imminent opposition, Islamists have experienced political struggles in contesting for electoral seats. The continuous harassment and

\footnotetext{
I PhD candidate at Department of Political Science, Kulliyah of Islamic Revealed Knowledge and Human Sciences, International Islamic University Malaysia (IIUM), Malaysia.

2 Graduate School Programme, Department of Political Science, Kulliyah of Islamic Revealed Knowledge and Human Sciences, International Islamic University Malaysia (IIUM), Malaysia.

3 Graduate School Programme, Department of Political Science, Kulliyah of Islamic Revealed Knowledge and Human Sciences, International Islamic University Malaysia (IIUM), Malaysia. 
peripheral treatment shown toward Islamist political parties in Turkey by the governing secularists have forced the Islamists to undergo a political reconstruction, especially in the case of AKP. This departure from the popular notions of Islamist parties signified a remarkable shift in the history of Turkish politics.

Since AKP's winning in 2002 elections, they have remained in power. They lost the majority of seats in 2015 but regained the majority after a snap election in the same year. Their consecutive political victories can serve as an inspiration to other political parties, particularly mainstream Islamist parties in the Middle East and Northern Africa that are currently experiencing a transitional democracy. This paper attempts to examine the electoral experience of AKP since coming to power in 2002. It investigates possible factors that contributed to their triumph from which positive lessons can be highlighted.

\section{THE BACKGROUND OF TURKISH POLITICS}

The downfall of the Ottoman Empire in Turkey in the early 2oth century marked the movement of secular modernism to erase the Islamic tradition in the Turkish modern-state. Led by Mustafa Kemal Ataturk, the Kemalist regime imposed modernity and embarked on the abandonment of Islam as the traditional belief and worldview of the Turks.

During the I930's the Kemalist doctrine was influenced by the dominant European authoritarian ideology that perceived modernization as westernization. In practice, Kemalism aimed to eliminate class, ethnic and religious sources of conflict by seeking to create a classless, national (unified as Turkish), secular (to cleanse any religious sign or practice in the public sphere) homogenized society (Yavuz 20II; Karasipahi 2009).

The Kemalist regime believed that modernity and democracy require secularism. Thus, to materialize the secularist agenda, Islam would either be kept under strict state control or confined to personal matters and private life. Secularism as an intellectual and political objective in Turkey has a long history of differentiating, marginalizing, and excluding large sectors of Turkish society. Turkish secularism is based on the idea of laicism that aims to transform society through the power of the state and eliminate religion from the public sphere. Any attempt to use religious arguments in public debates, even in the Turkish parliament, could be used as grounds to ban that party or exclude that group (Rabasa and Larrabee 2008).

\section{Turkey and Laicism}

The term "laicism" refers to "an anticlerical worldview and ideology that are based on secular processes. It provides for a strict institutional separation of state and religion, i.e., of political and religious authority. Accordingly, unlike under secularism, the laicist state keeps completely out of all religious matters" (Karakas 2007: 7-8).

In the case of Turkey, although the term laicism is used, the practical political objective of Turkish laicism is secularization. The term laicism has been part of the Turkish constitution since 1937. It is defined as:

a civilized way of life that forms the basis for an understanding of freedom and democracy, for independence, national sovereignty, and the humanist ideal, which have developed as a result of overcoming medieval dogmatism in favor of the primacy of reason and enlightened sciences....the court determined that "in a laicist order [...] religion is freed from politicization, is discarded as an instrument of power, and is assigned the proper and honorable place in the conscience of the citizens (Rumpf I999: I64-I90).

Thus, the goals of Turkish laicism are secularization and modernization of state and society and the removal of religion from politics. Arguably, no other Muslim state has experienced anything as radical as the "reforms" that targeted all areas in which religion had a presence in Turkey. The reforms included a closure of all Islamic schools, religious orders and religious educational institutions, a replacement of Islamic law by civil law, the use of Latin script, the adoption of the Gregorian calendar and the introduction of active and passive female suffrage along with compulsory 
education. Further to these reforms, the Kemalist government passed the law promoting Western-styled dress codes and banned the display of religious symbols in public facilities and areas (Karakas 2007: 9).

The Kemalist regime legitimized the state as the sole agent of change which meant that any and all changes and reforms would be considered "modern" and acceptable only if they were carried out by the state i.e. the Kemalist regime. The regime suppressed all kinds of civil movements as it moved to consolidate itself as the single most powerful authority in the country. One of the goals of the Kemalist regime was to create a new society that was neither democratic nor liberal but authoritarian. Despite these radical reforms, no national mass protest movement developed that could potentially jeopardize the Kemalist state-building plan until the I99os.

\section{Civil-Military Relations in Turkish Politics}

The Turkish armed forces remain a formidable presence in Turkish politics. They have always occupied a central place in Turkey's political agenda. Historically, the strong presence of the military in the Turkish polity and society can be traced back to the end of the i3th century when the Ottoman state was founded in northwestern Anatolia. In the Ottoman-Turkish polity, the military has always enjoyed significant privileges and played a crucial role in its political system (Varoglu and Bicaksiz 2005). Prior to the creation of modern Turkey, the military had already attained a prominent role. Prominent military personnel and distinguished veterans became part of the nation's decision-making body named the kurultay (the assembly) and enjoyed a clear influence on the emperor.

In a continuation of this policy, the Turkish military has continued to benefit from the privilege of an autonomous position in the Kemalist regime. The Turkish military sets the agenda for security and enlists the internal and external mechanisms to support that agenda. In this regard, since the I980s, Kurdish nationalism and Islamic groups have been perceived as the main internal threats to the Kemalist regime.
In its role as guardian of democracy, secularism, and national unity against Islamist, ethnic separatist, and sectarian challenges, the military has seen fit to intervene in Turkish politics several times either by way of traditional and direct methods such as coup d'états (i.e. the interventions of 1960, I971 and 1980) or more recently by new, indirect and postmodern methods such as posting digital memorandums and seeking civil society support. For example, on the 28th of February 1997, the military pressured the Islamist-led government (the coalition of the Welfare Party and the Truth Path Party) to resign and allow another civilian government to take power.

However, the traditional role of the military in civilian politics as a key actor in Turkish political life has been restricted to Turkey's democratic options and limited by Turkey's bargaining position in its European Union (EU) bid. Turkey has traditionally regarded its military strength through its participation in international organizations such as NATO. Yet in the EU accession process, the Turkish military has come to be considered a weakness. The questionable Democratic Control of the Armed Forces (DECAF) in Turkey has received criticism from European circles; the military sphere has become a domain where action must be taken as part of the fulfillment of the Copenhagen criteria and is a condition of EU membership.

In the light of a significant paradigm shift in Turkish politics in recent years and with the noteworthy success of the AKP in transforming Turkish politics and society, the relevancy of civil-military relations in Turkey has received considerable attention by politicians, analysts and researchers alike. Ersel Aydinli (2009: 582) argues that, regardless of the Turkish army's opposition to the reforms carried out by the AKP, the majority of Turkish nationals strongly oppose the army's intervention in national politics. In view of the national rejection of military intervention into the affairs of civil society, it can safely be surmised that the majority of Turkish nationals are in favor of reducing military influence in civil society, although they still hold the guardianship status of the Turkish military in high regard. 
The societal expectations of the Turkish army's mission seem to be moving towards the progressive perspective, but some in the army are naturally having a hard time making this transition. To be fair, the fact is that Turkey faces some genuine and acute security challenges, such as those posed by Kurdish separatists, and so answering the question of which security matters the Turkish army should prioritize becomes difficult (Aydinli 2009: 588).

To avoid seriously undermining its credibility, the army leadership has to remain firm in their adoption of progressive thinking. It should remember that Turkish society has always wanted progressive changes for a better economy, better democracy, and better integration with the West. It should not exaggerate calls for military intervention as this is expressing the sentiments of marginal elements. It is important to recall the 2007 demonstration which highlighted the slogan "neither Shari'a nor coup". This strong statement indicates that the public absolutely refuses all brands of radicalism and fringe political positions. What the people demand is to move Turkey towards the West in a safe and non-extreme manner in order to prevent any serious damage to the Turkish identity.

The traditional Turkish civil-military paradigm has been a by-product of a special historic relationship between the vast majority of Turkish society and its conscript army. Therefore, it can not be understood or conceptualized without understanding the dynamics of Turkish societal instincts such as its deep fear of insecurity and disorder, which are at the core of its bond with the army. It appears that, "the more Turkish society can control such fears by building up further confidence in democracy and political processes, the greater the will becomes to turn a direct bond with the army into an indirect one under civilian oversights" (Aydinli 2009: 595). The signs of such a move point to a paradigm shift in Turkish civil-military relations. It appears that a growing segment of the leadership of the Turkish army has grasped the importance of this shift and what it means for the Turkish army and is bowing to its demand.

\section{REFAH PARTY}

During the I990s, opposition to the Kemalist regime gained momentum. This was viewed by secular Kemalists as jeopardizing the status quo of the regime. The most significant opponent was the Refah Party. The Refah Party is an Islamic party with an objective to transform Turkey from a secular to an Islamic state. It believed that the lack of Islamic ideals in Turkish politics was an impediment to the spiritual and physical development of Turkey's Muslim majority. Therefore, the party opposed secularist groups and was successful in the elections during I990s. Most of the party's members were old-fashioned and conservative.

Initially, the group was formed in 1969 under the conservative and prominent leadership of Necmitten Erbakan. It arose largely as a reactionary political force to the long standing status quo of the Kemalists' vanguard. The emergence of Erbakan's camp began a significant historical epoch in Turkish politics. Erbakan began his political career in 1969 when he was appointed as an independent candidate into the parliament (Meyer 1998). In the following year, the Milli Nizam (National Order) Party was established but it was eventually closed in I97I as a result of a military coup. The party's leader was forced to reestablish itself under the new name of the Milli Selamet (National Soundness) Party (Meyer 1998).

There were constant fluctuations in the political career of Erbakan and his party. Since coming into power, challenges arising from military dissatisfaction and competition from political opponents continuously harassed the government. As a result, several coups successfully closed down Erbakan's camp. He and other party leaders were eventually banned from politics in I980. After a successful military coup, the Refah Party or Welfare Party was established in 1983 under the leadership of Ali Turkmen. However, Erbakan's story did not end there, he was working behind the scenes (Gulalp 200I). When the ousted leader was given political opportunity, he emerged from behind the political curtains and became the official leader of the Refah Party in 1987. Surprisingly, the Refah Party joined the elections in the I990s 
and gained great popularity (Gulalp 200I). The party was chosen by the people on the grounds that they spoke the language of socio-economic justice and equality in poor urban neighborhoods and they filled the void created by the collapse of statism and the ensuing crisis of modernist ideologies upon which it was based, such as nationalism and socialism. The Refah Party represented a post-nationalist and postsocialist sense of "justice" (Gulalp 200I).

The Refah Party criticized the Kemalist authoritarian system as having failed to meet the needs of the people, including the Kurdish people. They viewed themselves as an important instrument and much needed agent to provide and ensure the welfare of society. Unfortunately, the modus operandi of the Refah Party led to tensions within Turkish society as a result of radical statements made by some of its members against the secular state of Turkey (Cox 1997). As mentioned above, any religious debate in the public sphere is seen as grounds to potentially ban the party. The constitutional court duly made an order banning the Refah Party from political participation in 200I (Justice and Development Party (AKP) n.d.). From then onwards, the party was outlawed and was prohibited from participating in any elections.

Because of these misfortunes, members of the Refah Party had to reestablish themselves under a new name. Erbakan set up a new party called the Fazalet Party, but given that it was an offshoot of the Refah Party, it was not officially recognized. As a result, the AKP was born. However, the proponents of the newly formed party such as Abdulah Gul and Recepp Tayep Erdogan adopted a different position from those employed by Erbakan. Abdulah Gul and Recepp Tayep Erdogan pursued a modernist and moderate approach to achieve Islamist aspirations of political governance significantly different to the strategies once pursued by the Refah Party.

\section{THE POLITICAL VICTORY OF THE AKP}

The rise of AKP indicated a new phase in the political landscape of Turkish politics. Its forma- tion as a successor to the Refah Party exhibited distinguishing features that drew considerable support from the Turkish people. Furthermore, it departed from its rigid political program to one that was more flexible which responded to the needs and interests of the majority. There were a number of contributing factors that describe the fluidity of AKP politics but in general the evolution of a modernizing Islamist political force was facilitated by external pressures for reform (Carroll 2004). Another distinct factor that paved the way for AKP's success was the economic crises that Turkey experienced in 2000-2001 which resulted in a major collapse in economic output (with negative growth of -7.4 percent in 2001) that was accompanied by rigorous IMF conditions of fiscal discipline and regulatory reforms (Justice and Development Party (AKP) n.d.).

Despite its recent inception, AKP joined the 2002 November elections. The 2002 elections represented an historical development in terms of providing socially minded Muslim parties the opportunity to restructure the political landscape and expand civil authority (Yavuz 2003: 256). The AKP gained 34\% of total votes (two-thirds of the seats in the 550-seat parliament) defeating all other political parties and marking the end of the governing coalition government that had been in power since I99I (Justice and Development Party (AKP) n.d.). This historic event heralded good fortunes for AKP with its ascension to political power and the positioning of Recep Tayyip Erdogan, the chairman of AKP, as the Prime Minister.

Consequently, another round of political fortune for the AKP transpired in the 2004 elections. The party increased its $34 \%$ vote, achieved in the November 2002 election to nearly $47 \%$; becoming the first government to win re-election in 20 years and the first since 1954 to increase its vote (Mulholland 2007). However, the 2007 presidential and parliamentary elections were a testing and turbulent year for the party. The opposition criticized the appointment of Abdullah Gul to the presidency as a threat to the established political system of the country. The AKP already controlled the prime ministry and par- 
liament, and control of the presidency would potentially allow it to dominate other branches of government because of the president's role as commander-in-chief of the military and his power to appoint Constitutional Court judges, the Higher Education Board, and university rectors - all still bastions of secularism (Migdalovitz 2007).

However, because of the Party's positive record in its previous terms and its responsibility for carrying out economic reforms that saw remarkable success, the AKP enjoyed the favor and confidence of the people and subsequently won the 2007 elections. The AKP consolidated its power with 341 of the 550 seats in Parliament. The opposition Republican People's Party (CHP) only managed to secure 97 seats. Recep Tayyip Erdogan maintained his position as Turkey's prime minister (Justice and Development Party (AKP) n.d.). The party's electoral success continued in the 2009 and 2011 elections. In 2011, it scored 50 percent of the vote and won 327 seats in the 550-member parliament, less than the 330 seats needed to put a new constitution to a referendum ("Erdogan triumphs," 20II). This triumph has made the party is getting closer to pursue its agenda which was to form a new constitution. As the Table 1 show of Turkish general election results, AKP managed to successfully maintain its majority in the parliamentary seats in three successive elections (Carkoglu 2002; Eligür 2007; Bipartisan Policy Centre 2014).

Table I: Turkish General Elections (2002, 2007, 20II)

\begin{tabular}{llll}
\hline & 2002 & 2007 & 2011 \\
\hline $\begin{array}{l}\text { Nationalist Action Party (Mil- } \\
\text { liyetci Hareket Partisi-MHP) }\end{array}$ & 8.34 & 14.3 & 13.01 \\
\hline $\begin{array}{l}\text { True Path Party (Dogru Yol } \\
\text { Partisi-DYP) }\end{array}$ & 9.55 & & \\
\hline $\begin{array}{l}\text { Republican People's Party } \\
\text { (Cuhuriyet Halk Partisi-CHP) }\end{array}$ & 19.40 & 20.8 & $25.98 \%$ \\
\hline $\begin{array}{l}\text { Justice and Development Party } \\
\text { (Adalet ve Kalkinma Partisi-AKP) }\end{array}$ & 34.28 & 46.6 & $49.83 \%$ \\
\hline
\end{tabular}

\section{WHO VOTED FOR AKP AND WHY?}

This discussion seeks to explain the demographics of who voted for the AKP. The surprising landslide victory of the AKP in the 2002 elections, which consequently united Turkey under one ruling party, and its consecutive winning electoral results make it necessary to identify and better understand those who voted for them.

As previously mentioned, the AKP faced many challenges and pressures especially from secular Kemalists. The AKP's nature and origin as a reincarnation of the Refah Party was seen by secular Kemalists as a threat to the political landscape of Turkey. However, in spite of their opposition, the AKP managed to attract the continuous support of the masses. The survey administered by World Values Survey explained that it was the working class of Turkish society where the AKP maintained its popularity (Tillman 20I4).

It is true that Turkey's conservative segment of society were inclined to AKP. However, not all of its supporters voted for AKP along ideological lines. In fact, it is shown in the survey that only $7.23 \%$ of the support base reflected ideological reasons for voting for AKP (Tillman 20I4). Others claim that the Islamist AKP not only won the support of religious Turkish Muslims but also the support of secularized Turks and Turkish minorities. These people voted for AKP as a vote of protest. Under the rule of the Kemalists reforms were confined solely to the cultural realm (Yavuz 2003: 25). One bold example of AKP's stand, that assured electoral support, was its pro-Kurdish position. The then President Erdogan's assertion of his support for cultural pluralism and tolerance of minorities, specifically his positive stand on the Kurdish problem attracted the support of the Kurdish minority (Akdag 20I4). As a result, the periphery was further marginalized and the country was ready for a political alternative (Taspinar 2005). The uniqueness of AKP was that they did not exclude other segments of society. This inclusive approach distinguished them from previous regimes. 


\section{APPROACHES AND STRATEGIES OF} AKP

This section emphasizes the approaches and strategies of the AKP throughout their involvement in the electoral process which researchers attribute to their political fortune. The approaches and strategies were accumulated from an investigation of books and articles relating to this issue. In addition, this work considers the approaches and strategies of the AKP on social, economic and political reforms. The following insights into AKP's approaches are taken from various secondary resources.

\section{Internal Approach}

Before the rise of the AKP, there was a political schism between the state and society. Because the Turkish political system was based on totalitarian and authoritarian ideologies embedded in kemalism/secularism, there was no room for liberal democracy and social pluralism (Sambur 2009). Political representation and involvement were denied to many social groups. As a result, the majority of the Turkish population felt alienated and isolated by the state and believed that the political establishment did not give them sufficient opportunity to fulfil their social, cultural and economic aspirations within the framework of human rights, the rule of law and liberal democracy. This made people very weak and the state very strong (Sambur 2009).

In contrast, the AKP's approach appealed to the masses as they bridged the gap between the state and society. Their approach was deemed to be bottom-up. Initially, AKP started to win the hearts of the Turkish people by being involved in social services. These social services subsequently translated into political support.

The AKP engaged people of very diverse backgrounds, from teachers, policemen, vendors, traders, and new Muslim intellectuals to humble shopkeepers and businessmen. The AKP utilized culturally rooted grassroots networks, personalities and cultural frames to project itself as the party for the 99 percent Muslim electorate. Most groups and networks are inspired by religion, even though they have been infused with the discourse of secularism and westernism along 80 years of Turkish political experimentation. Furthermore, almost all Islamic groups offer some form of community service, making such activities more common than prayer groups. These groups act as a social base of Islamic identity and have a very strong commitment to social justice and direct participation in communal outreach programs.

In addition to its leader and the group of recognized Islamically oriented politicians within the AKP, the hybrid identity of the party also played an important role in its electoral success. The party is "western" in the terms of stressing human rights, the rule of law, economic liberalism, and respect for popular will as the guiding principles of public policy. Moreover, it attempts to rearticulate the Ottoman Islamic ethos as the spirit of tolerance, accommodation, and co-existence of faiths, cultures, and ideas. This modernist and western-influenced Islam appealed to many secularized urban and wellto-do Turks who felt that party could provide a much-needed correction to the prevailing corrupt and authoritarian political structure (Yavuz 2003: 267-26I).

In the light of the points raised above, the AKP differed substantially from their Kemalist counterparts. The Kemalist approach to modernize Turkey was not bottom-up which consequently marginalized other segments of society. The bifurcation between the elite and the masses prevented reform from below resulted in economic and social polarization between secularists and devout Muslims as well as between rural classes and urban areas (Kasaba 1997). However, the coming of AKP restructured the system. The AKP, as a peripheral party, managed to appear as a center-right party. "The Justice and Development Party (AKP) despite its avowedly Islamic background has proved to adapt and transform itself and the system by presenting to the public as a successful center-right party, which supports democracy, secularism, human rights and economic development" (Kasaba 1997). The latter marginalized the 
society as a result of its political ideology but the former bridged the schism that separated society and the state. Moreover, the AKP delivered social services that the latter failed to achieve.

\section{Economic and Political Reforms}

The AKP was not only responsible for social reforms but was also responsible for many economic and political reforms. These successes led to the re-election of AKP. The party was reelected largely on the basis of the country's economic performance and its commitment to continued economic liberalization (Justice and Development Party (AKP) n.d.). The internal and external pressures ironically translated into political opportunities. Its aspiration to EU membership and the political challenges within the country justified the modification and flexibility of AKP's economic and political approach. An example of this is that in 2006 Turkey's economy grew by an average of $8 \%$ and per capita income (based on purchasing power parity) climbed to $\$ 8,400$ - up from $\$ 6,700$ in 2002 (Kiefer 2007). In addition, the biggest success was the AKP's ability to attract investment. "Between 1980 and 2003, the country saw $\$ 18$ billion in FDI. Between 2003 and 2006, however, FDI jumped from $\$ 1.7$ billion to $\$ 20$ billion. More than $\$ 30$ billion is expected in 2007. Perhaps most importantly, FDI financed 60 percent of the nation's account deficit in 2006" (Kiefer 2007). Unlike other Muslim countries in the region, Turkey has been cajoled, pressured and encouraged by the West in its journey toward full and mature democracy (Carroll 2004). In addition, the AKP surprised its critics for pushing harder (and more successfully) for liberal and democratic reforms than any previous Turkish government (Carroll 2004).

Admittedly, the AKP's wise tactics harnessed pro-EU attitudes in a bid to protect themselves against the suppressive policies of the Turkish secularist establishment (Yilmaz 2007). Because of its accommodation and facilitation of western ideals and values, it still enjoys support from the US and EU. "What we are seeing are the demands of the
EU and pro-Islamic groups overlapping for the first time in Turkish history, with Islamic groups finding in the West an ally that can protect them against the excesses of the Kemalist state," notes Ihsan Dagi, a professor of international relations at the Middle East Technical University in Ankara (Smith 2003).

\section{LESSONS LEARNED?}

The AKP's electoral experience and victory offer a number of significant lessons. The AKP differs in its approaches and strategies from previous Turkish regimes, like that of the Kemalist secular forces and the Refah Party. The party espouses a style that draws relatively high support from all sectors of the society. Its bottom-up approach has proven to be an advantage for the party over contending parties.

On the social level, the party successfully bridged the gap between the state and society. This provided space for the public for political participation which was deprived to them during the Kemalist administration. In addition, its early work as a social movement delivering social services eventually translated into political support. On the economic and political level, the AKP remains in power because it has been responsible for the country's economic performance. Economic liberalization, human rights and upholding democratic ideals are advocated by the party and as such inspire the renewed support of the public. Westernism was seen by the AKP as a gambit to secure themselves against the Kemalist opposition. In this regard, the AKP bolstered its relations with Europe. On religious aspects of the nation, the party grasped a keen of understanding of the role of religion in Turkish society. It learned not to stress an Islamic ideology as part of its political manifesto. However, Islam is protected by the party and at the same time does not undermine the secular nature of the state. The party has shown identity transformation as a part of a continuous adaptation process by the new Islamic logic based on broad political participation at both domestic and global levels (Kosebalaban 2005). This experience of AKP, therefore, can be taken as a model for other parties with Islamic leanings in other Muslim countries. 


\section{CONCLUSION}

There are lessons to be learned from AKP's electoral triumph. It is an undeniable fact that different countries have their own unique political experiences and as such the experiences of the AKP and its subsequent political strategies may not necessarily be applicable to all political parties. Turkey also has a number of internal issues that are not experienced by other countries. However, some lessons are bound to be relevant to other parties. Given the fact that AKP arose from Islamic and conservative parties, mainstream Islamist parties in the Middle East and North Africa may find AKP's successes relevant.

Some of the major lessons to draw from the experience of AKP are; firstly the adversities the Refah Party had gone through taught AKP to depart from politics of rigidity to flexibility as they dealt with the complex demands and needs of society. Their adoption of flexible policies is a clever move to respond to and to accommodate the conflicting and diverging interests of society. Investing their support at the grassroots level translated into political support. This was another significant move responsible for their success and widespread popularity. More importantly, they developed a strategic understanding of when and how to advance their agenda. Moreover, a pro-west attitude was strategically important as security against attacks from secularists. To be defended by the west was a wise approach by the AKP. Finally, religion was not made as an apparatus for political maneuvering. They did not try to attack the secular nature of Turkey while protecting Islam as the religion of the state.

\section{REFERENCES}

Akdag, Gul Akdag. (2014) Ethnicity and Elections in Turkey, Party Politics and the Mobilization of Swing Voters. New York: Routledge.

Ayoob, Mohammed Ayoob. (2007).The Many Faces of Political Islam: Religion and Politics in the Muslim World. Michigan: University of Michigan Press.

Bilal Sambur. (2009). The Great Transformation of Political Islam in Turkey: The Case of Justice and Development Party and Erdogan.
European Journal of Economic and Political Studies, 2, (2)

Bipartisan Policy Centre. (April 3, 20I4). Comparing Recent Turkish Election Results: Election Analysis, Turkey Initiative. Retrieved from Comparing Recent Turkish Election Results: Election Analysis. 20i6. http:// bipartisanpolicy.org/wp-content/uploads/ sites/default/files/Turkey\%2oLocal\%20 Election\%2oResults.pdf (Accessed 15 October)

Carkoglu, Ali Carkoglu. (2002). Turkey's November 2002 Elections: a New Beginning?, Middle East Review of International Affairs, 6(4), December.

Carroll, Thomas Patrick Carroll. (2004). Turkey's Justice and Development Party: A Model for Democratic Islam?. (2004). Middle East Intelligence Bulletin, 6. 6-7). Retrieved from http:// www.meforum.org/meib/articles/0407_ tr.htm. (Accessed 2I September, 20II).

Cox, M.K.L. (1997)., "Turkish Islamism: The Refah Party," (A research paper, ACSC, I997), A research paper, ACSC, I2-I3. Retrieved from $<$ http://www.dtic.mil/cgi-bin/GetTRDoc?L ocation $=\mathrm{U}_{2} \&$ doc $=$ GetTRDoc.pdf $>$ (accessed I4 October 20II)

Eligür, Banu. (2007). The Changing Face of Turkish Politics: Turkey's July 2007 Parliamentary Elections, Middle East Brief, no. 22. Retrieved from http://www.brandeis.edu/crown/ publications/meb/MEB22.pdf (Accessed October 2016)

Erdogan triumphs in Turkey's election. (20II). Retrieved from http://www.guardian.co.uk/ world/20II/jun/I2/erdogan-triumphs-turkeys-election-ak-party. (Accessed I October, 20II)

Giannotta, Valeria. (20I3). AKP as Political and Social Order. İstanbul Sabahattin Zaim University. Retrieved from http://www.izu.edu.tr/Assets/ Content/file/20130613-04.pdf. Accessed I6 October 2016.

Gulalp, Haldun Gulalp. (200I).Globalization and political Islam: The Social Bases of Turkey's Welfare Party. Int'l Journal of Middle East Studies. 33, 433-448.

Justice and Development Party (AKP) Adalet ve Kalkinma Parti (AKP). Retrieved from http:// www.globalsecurity.org/military/world/ europe/tu-political-party-akp.htm (Accessed I5 September, 20II)

Karakas, Cemal. (2007). "Turkey: Islam and Laicism Between the Interests of State, Politics, and Society", PRIF Reports No. 78. Frankfurt am Main: Peace Research Institute Frankfurt. 
Karasipahi, Sena Karasipahi. (2009). Muslims in Modern Turkey: Kemalism, Modernism and the Revolt of the Islamic Intellectuals. London \& New York: I.B. Tauris \& Co. Ltd.

Karaveli, Halil M. (March 20ıo). An Unfulfilled Promise of Enlightenment: Kemalism and Its Liberal Critics. Turkish Studies. Vol. II, No. I, 85-102.

Kasaba, R. (I997) 'Kemalist Certainties and Modern Ambiguities', in S. Bozdoğan and R. Kasaba (eds) Rethinking Modernity and National Identity in Turkey Seattle: University of Washington Press. Cited from Giannotta, Valeria. AKP as Political and Social Order. Retrieved from http://www.izu.edu.tr/Assets/ Content/file/201306I3-04.pdf. Accessed i6 October 2016.

Kiefer, Meral Varis. (2007). Kiefer, Turkey's Economic Future and the AKP. The Washington Institute, Policywatch 1226. Retrieved from http://www.washingtoninstitute.org/policyanalysis/view/turkeys-economic-future-andthe-akp. (Accessed 24 October 20I6)

Kosebalaban, H. (2005) “The Impact of Globalization on Islamic Political Identity: The Case of Turkey," World Affairs, I68(I): 27-37.

Meyer, James H. (I998) Refah and Susurluk: Turkey's troubled democracy. East European Quarterly. $32(4), 489$.

Migdalovitz, Carol. (July II, 2007). Turkey's 2007 Elections: Crisis of Identity and Power. CRS Report for Congress. Retrieved from .http:// www.fas.org/sgp/crs/mideast/RL34039.pdf. (Accessed I October, 20II)

Mulholland, Niall. (2007). AKP wins Turkey's election clash. (2007) Socialism Party Magazine, issue II2. Retrieved from http://www. socialismtoday.org/II2/turkey.html (Accessed I7 September, 20II)

Rabasa, R. and Stephen F. L. (2008). "The Rise of Political Islam in Turkey". Santa Monica: RAND.

Rumpf, Christian. (I999). Fundamentalismus und Religionsfreiheit in der Türkei in Verfassung, Rechtund Praxis, in: Verfassung und Recht in Übersee (VRÜ), Vol. 32, pp. I64-I9o (I66). Cited in Cemal Karakas, "Turkey: Islam and Laicism Between the Interests of State, Politics, and Society”, PRIF Reports No. 78, (Frankfurt am Main: Peace Research Institute Frankfurt, 2007), 8.

Sambur, Bilal. (2009). "The Great Transformation of Political Islam in Turkey: The Case of Justice and Development Party and Erdogan,
European Journal of Economic and Political Studies, vol. 2, no.2, II7-I28.

Smith, Helena. (2003). New Breed of Islamic Politicians Start to Find Their Feet. The Guardian. London. Cited from Thomas Patrick Carroll. (2004). Turkey's Justice and Development Party: A Model for Democratic Islam? Middle East Intelligence Bulletin, 6. 6-7). Retrieved from http://www.meforum. org/meib/articles/o407_tI.htm. (Accessed 2I September, 20II).

Taspinar, Omer. (2005) Kurdish Nationalism and Political Islam in Turkey: Kemalist Identity in Transition, .New York: Routledge.

Tillman, Erik R. (May 29, 20I4). The AKP's working class support base explains why the Turkish government has managed to retain its popularity during the country's protests. European Politics and Policy, London School of Economics. Retrieved from <http:// blogs.lse.ac.uk/europpblog/2014/05/29/ the-akps-appeal-to-the-working-classexplains-why-the-turkish-government-hasmanaged-to-retain-its-support-during-thecountrys-protests/.>

Yavuz, M. Hakan (2003) Islamic Political Identity in Turkey. New York: Oxford University.

Yavuz, M. Hakan. (20II). "Secularism and Islamic Movement in Turkey." Retrieved from <http:// www.yale.edu/macmillan/rps/islam_papers/ Yavuz-030I08.pdf $>$ (accessed on Io November 2OII).

Yilmaz, Hakan. (2007) Islam, Sovereignty, and Democracy. Middle East Journal. 6I (3). Varoglu, A. Kadir and Bicaksiz, Adnan. (Summer 2005). "Volunteering for Risk: The Culture of Turkish Armed Forces", Armed Forces \& Society, vol. 3I, no. 4, 583-598.

Aydinli, Ersel. (Autumn 2009). "A Paradigmatic Shift for the Turkish Generals and End to the Coup Era in Turkey", Middle East Journal, vol. 63, no. 4,582 . 